\title{
EMSY wt Allele
}

National Cancer Institute

\section{Source}

National Cancer Institute. EMSY wt Allele. NCI Thesaurus. Code C111827.

Human EMSY wild-type allele is located in the vicinity of $11 \mathrm{q} 13.5$ and is approximately 108 $\mathrm{kb}$ in length. This allele, which encodes protein EMSY, plays a role in repression of transcription and may play a role in DNA repair. 